\title{
DETERMINATION OF CRIMINAL CAPACITY FOR CHILD OFFENDERS - INTERFACING THE PROCEDURAL REQUIREMENTS OF THE CHILD JUSTICE AND CRIMINAL PROCEDURE ACT
}

\author{
Michelle Karels \\ LLB LLM \\ Senior Lecturer, Criminal and Procedural Law \\ University of South Africa, Pretoria (UNISA) \\ Letitia Pienaar \\ LLB LLM \\ Lecturer, Criminal and Procedural Law \\ University of South Africa, Pretoria (UNISA)
}

\section{SUMMARY}

This submission considers the effect of the doli incapax presumption contained in the Child Justice Act on the procedural reality of South African child-justice process. We further consider Chapter 13 of the Criminal Procedure Act as it pertains to child offenders, both those considered rebuttably incapax, and those to whom the question of age-based capacity do not apply. We conclude that the doli incapax provisions, when interfaced with the tenets of the Criminal Procedure Act, that address mental pathology, are incompatible in so far as they pertain to child justice.

\section{1}

\section{INTRODUCTION}

Historically, criminal justice systems were designed for adults and children were expected to adapt to, and function within the given system. ${ }^{1}$ The Child

Hawkridge "Children as Perpetrators" in Kaliski (ed) Psycholegal Assessment in South Africa (2006) 251 and 252, explains that children were previously incarcerated with adults since it was a system for adults. Both the Child Justice Act 75 of 2008 and the Correctional Services Act 111 of 1998 currently prohibit the detention (pre-trial, remand or sentenced) of adults and children in the same facility. 
Justice $\mathrm{Act}^{2}$ purportedly establishes a separate criminal justice system for children who are in conflict with the law. ${ }^{3}$

Further to the establishment of a distinct procedure for children in conflict with the law, the Child Justice Act provides for the evaluation of the criminal capacity of a child where such is disputed. ${ }^{4}$ The question arising therefrom, however, is if the process created in the Child Justice Act creates a distinct inquiry to that provided for in the Criminal Procedure Act. ${ }^{5}$ This submission investigates the nature and scope of both the Child Justice Act as it pertains to criminal capacity and the Criminal Procedure Act as it pertains to mental capacity to understand proceedings as well as to the defence of mental defect or illness.

Both systems are considered for their consequences and the argument advanced that tandem operation is ill-conceived and illogical within the ordinary scope of child justice. The authors thereafter offer recommendations based on the above consideration supplemented by a comparative review of the position in England/Wales.

We proceed hereunder from a brief analysis of both sections 10 and 11 of the Child Justice Act and Chapter 13 of the Criminal Procedure Act.

\section{REBUTTABLE PRESUMPTION OF CRIMINAL INCAPACITY IN THE CHILD JUSTICE ACT}

The Child Justice Act amended the common-law position pertaining to the minimum age of criminal capacity. The previous, Roman-law-inspired common-law position dictated that children between the ages of 7 and 14 years were deemed doli incapax.

The Child Justice Act statutorily altered and regulated criminal capacity in section 7(2) which created a rebuttable presumption of incapacity for children aged between 10 and $14 .^{7}$ The evidentiary burden is that of the State to prove criminal capacity in this age group. ${ }^{8}$ The determination of

\footnotetext{
75 of 2008 (hereinafter "the Child Justice Act").

See the preamble to the Child Justice Act.

S 11 of the Child Justice Act.

51 of 1977 (hereinafter "the Criminal Procedure Act").

Walker "The Requirements for Criminal Capacity in Section 11(1) of the new Child Justice Act 2008: A Step in the Wrong Direction" 20111 SACJ 33, 32. S 7(3) of the Child Justice Act confirms the intention of the legislature to amend the common-law position to the extent as set out in $\mathbf{5} 7$ of the Child Justice Act. Also see Gallinetti "Child Justice in South Africa: The Realisation of the Rights of Children Accused of Crime" in Boezaart (ed) Child Law in South Africa (2009) 650, who briefly sets out the common-law position that existed prior to the Child Justice Act which came into operation on 1 April 2010. See further Hawkridge in Kaliski (ed) Psycholegal Assessment in South Africa 252 for the common-law position.

$7 \quad S 7(2)$ of the Child Justice Act. See Gallinetti in Boezaart (ed) The Child Law in South Africa 650 , who explains that in effect the common-law presumption of doli incapax was retained in the Child Justice Act, but that the minimum age of criminal capacity was moved upwards (from 7 years to 10 years).

8 S 11(1) read with s 7(2) of the Child Justice Act. Also see Kruger Hiemstra Suid-Afrikaanse Strafproses 7ed (2010) 789. See further South African Law Commission (2000) Juvenile Justice Report Project 10629 http://www.justice.gov.za/salrc/reports/r_prj106_juvjus $2000 \% 20 j u l . p d f$. See further Gallinetti in Boezaart (ed) Child Law in South Africa 650, where
} 
capacity is a matter which must be proved beyond a reasonable doubt. The test for capacity entails a consideration of whether a particular child could (a) distinguish between right and wrong; and (b) act in accordance with that appreciation. ${ }^{9}$ The doli incapax presumption offers automatic protection to a child, which protection is activated by the mere fact that a child is a certain age. ${ }^{10}$ Criminal incapacity in this age group is not a defence to a criminal charge but rather a presumption of law.

The determination of criminal capacity is a pre-trial matter which is addressed by:

(a) Probation officer: Assessment - the probation officer is required, where necessary, to express an opinion in assessment as to whether expert opinion regarding criminal capacity would be required at trial.

(b) The prosecutor in terms of section 7(2) who must consider four categories of information:

Category 1: The Child - the prosecutor must consider the educational level, cognitive ability, domestic and environmental circumstances, age and maturity of the child.

Category 2: The offence - the nature and seriousness of the alleged offence.

Category 3: The impact - the prosecutor is required to consider the impact of the alleged offence on the victim and the community.

Category 4: The procedural specifics - the prosecutor must consider the contents of the probation officer's assessment report, appropriateness of diversion and the prospect of establishing capacity if the matter is referred to the preliminary inquiry stage.

(c) The preliminary inquiry magistrate or trial court: the preliminary inquiry court or child-justice court is required to consider all information contained in the probation-assessment report as well as all information placed before the court in prior proceedings. The court of preliminary inquiry or trial is further empowered to order the evaluation of the

it is pointed out that the criminal capacity of a child over the age of 10 years but under 14 years, has to be proved beyond a reasonable doubt. Also see Hawkridge in Kaliski (ed) Psycholegal Assessment in South Africa 257, who confirms the position that existed even prior to the enactment of the Child Justice Act, namely that the prosecution has to rebut the presumption of doli incapax.

9 S 11(1) of the Child Justice Act. This correlates with the requirements set out in $s 78$ of the Criminal Procedure Act which sets out the test for criminal capacity. See Skelton and Badenhorst The Criminal Capacity of Children in South Africa (2011) 19 and 22, where they point out that the application of the doli incapax presumption implies that the State has to prove that the child is more mature than could be expected of a child between the age of 10 and 14 years and therefore s/he has criminal capacity. It should accordingly, be the exception to the rule that a child between 10 and 14 will be prosecuted because of this fact having to be established. The presumption is however, not always applied in this fashion.

10 South African Law Commission (2000) Juvenile Justice Report Project 10628 http://www.justice.gov.za/salrc/reports/r_prj106_juvjus_2000\%20jul.pdf. See further Gallinetti in Boezaart (ed) Child Law in South Africa 650. See also Skelton and Badenhorst The Criminal Capacity of Children in South Africa 29. 
criminal capacity of a child. This evaluation of the criminal capacity of the child is undertaken by a psychologist or psychiatrist and must include an analysis of the cognitive, moral, emotional, psychological and social development of the child. This particular assessment relates to the capacity of the child to act and cannot be misconstrued as a mentalhealth inquiry or observation.

\section{CAPACITY TO UNDERSTAND PROCEEDINGS IN TERMS OF THE CRIMINAL PROCEDURE ACT}

From the outset it is clear that section 77 of the Criminal Procedure Act is not akin to a determination of capacity in terms of the Child Justice Act. Section 77 of the Criminal Procedure Act still attaches consequences to the actions of an accused person such as detention in a psychiatric hospital or prison. A section 77 determination is a determination of capacity to make a proper defence and not a question of the ability to appreciate the difference between right and wrong and act in accordance with that appreciation. Juxtaposed to the position of a child between 10 and 14 years of age; section 77 is a matter of mental capacity and not capacity of maturity or lack thereof. The child is unable to proceed to trial due to a lack of developmental capacity; an adult cannot be made to proceed to trial based on a lack of cognitive understanding of the proceedings. It is perfectly conceivable that a child is capable of cognitive understanding or conative appreciation, but where the State cannot prove such beyond a reasonable doubt; no criminal consequence can be attached to the child's conduct. Stated in the alternative section 77 is a "now" inquiry - can the accused understand the proceedings in court. A child offender may very well be able to meet the "now" test of comprehension but other factors may render the child incapax.

\section{CRIMINAL RESPONSIBILITY AND MENTAL DEFECT IN THE CRIMINAL PROCEDURE ACT}

Section 78 of the Criminal Procedure Act is premised on the presumption of mental capacity to appreciate the wrongfulness of an act or omission and to act in accordance therewith. ${ }^{11}$ The presumption is commonly referred to as the presumption of sanity although such terminology cannot be supported. Terminology notwithstanding:

78. (1A) Every person is presumed not to suffer from a mental illness or mental defect, so as not to be criminally responsible in terms of section 78 (1) until the contrary is proved on a balance of probabilities.

In terms of the Criminal Procedure Act any person who commits a positive act or omits to act while suffering under a mental defect or illness shall not be held criminally responsible for such act or omission. The presumption of mental competence or health must therefore be rebutted on a balance of probabilities which is a lesser burden to that operative in a criminal finding of guilt. The mechanism to refute is provided in section 79 of the Criminal Procedure Act. The burden to rebut is placed on the party who avers lack of

11 Kruger Hiemstra Suid-Afrikaanse Strafproses 234. 
mental capacity or mental illness. The accused does not escape liability through the provisions of section 78 since detention in a psychiatric hospital, prison or institution can be ordered depending on the circumstances and seriousness of the charge. ${ }^{12}$ The accused is, however, found not guilty on the basis of incapacity and in some instances the accused can be released conditionally or unconditionally. The accused is, however, adjudged not guilty by reason of mental illness or intellectual disability.

Clearly section 78 poses a defence to a criminal charge by reason of mental illness or defect. This defence is likewise available to a child-accused as confirmed in section 48(5)(b) which empowers the court of preliminary inquiry to postpone said inquiry to allow for a psychiatric evaluation.

Section 78 of the Criminal Procedure Act relates to mental defect or illness whereas the doli incapax presumption in the Child Justice Act is premised on the maturity or evolving capacities of the child. The child is not presumed incapable due to mental defect but rather due to immaturity and/or a variety of situational circumstances which affects the child's ability to distinguish between right and wrong and to act in accordance with that appreciation. An issue arises, however, where a child presumed to lack criminal capacity and who suffers from mental defect or illness is brought before the court. The tests upon which the doli incapax presumption and the test for mental illness or defect rest are in essence identical but the burden of proof and onus differs. Since the Child Justice Act makes no reference to the specific applicability of section 78 to a child, the application of logic directs the procedure. This position is, however, untenable in the context of the best-interest standard.

Since the provisions of the Child Justice Act and the Criminal Procedure Act seem to be in contrast to each other with regard to rebuttable presumptions and burden of proof, the question arises if these two modes of assessment can and should function in tandem in the case of children between 10 and 14. A secondary inquiry related to the first is whether the procedure provided for the assessment of mental defect or illness, in terms of section 79 of the Criminal Procedure Act, meets the best interest standard for children over the age of rebuttable incapacity. Stated differently, does the procedure for mental assessment in section $79^{13}$ of the Criminal Procedure Act, form part of a child-friendly system of justice?

The authors approach the first inquiry within the framework of the determination of criminal capacity within the Child Justice Act and then proceed to the second inquiry thereafter.

12 In the case where the accused was charged with a serious offence which, in the public interest, warrants detention. This is the case where the accused is charged with murder, culpable homicide, rape, compelled rape or any other offence which involves serious violence. If the offence in question does not involve one of these offences the court can order that the accused be admitted and detained as an involuntary mental health-care patient or that he be released conditionally or unconditionally.

13 In order to determine if an individual lacks the mental faculties to understanding proceedings or to determine whether the act or omission is excusable by mental illness or defect; an assessment in terms of s 79 of the Criminal Procedure Act takes place. S 78(2) specifically mandates a s 79 enquiry. 


\section{EVALUATION FOR CRIMINAL CAPACITY OF CHILDREN BETWEEN THE AGE OF 10 AND 14 YEARS}

\section{Child Justice Act}

The Child Justice Act stipulates that, where a child in conflict with the law is handed a written notice to appear, summonsed to appear or arrested, an assessment by a probation officer must take place. ${ }^{14}$ Probation officers' assessments are not a substitute for the evaluation of criminal capacity, which is conducted by a suitably qualified person in terms of the Child Justice Act. ${ }^{15}$ The probation officer, where capacity is at issue, is permitted to express whether specialist enquiry into the child's capacity may be necessary. Likewise assessment is not synonymous with enquiry into the mental capacity of an accused in terms of the Criminal Procedure Act. ${ }^{16}$ Care should be taken to use the correct terminology as it can easily create confusion if "assessment" is used loosely and as a collective term for any type of pronouncement on the criminal capacity of the child.

The assessment, bar the application of chapter 6 diversion, is mandatory ${ }^{17}$ and takes place before the preliminary inquiry (which is akin to the first appearance of an adult accused). The assessment by the probation officer fulfils many purposes inter alia to establish if the child is in need of care and protection, ${ }^{18}$ in which case the matter will be referred to the Children's Court. ${ }^{19}$ The probation officer must indicate in his assessment report, the possible criminal capacity of the child between 10 and 14 years and measures to be taken in order to prove criminal capacity. ${ }^{20}$ The probation officer is further required to state whether expert evidence pertaining to the criminal capacity of the child will be necessary, ${ }^{21}$ which must be indicated in the assessment report. The probation officer is thus required to form a subjective opinion as to the capacity of the child to act with the requisite degree of understanding and appreciation. The Child Justice Act does not rest this determination solely with the probation officer but further permits the court of preliminary inquiry and child justice to query the child's criminal capacity.

The inquiry magistrate or the child-justice court may (authors' emphasis) make an order for the evaluation of the criminal capacity of the child by a

$\mathrm{S} 34$ of the Child Justice Act.

S 11(3) of the Child Justice Act.

S 78 read with s 79 of the Criminal Procedure Act.

S 34(1) of the Child Justice Act. The assessment can be dispensed with if it is deemed to be in the best interest of the child. The fact that the assessment was dispensed with must be noted by the magistrate in terms of $s 41(3)$ of the Child Justice Act.

18 S 35(1)(a) of the Child Justice Act.

19 In accordance with $\mathrm{s} 30$ of the Child Justice Act.

20 S 40(1)(f) of the Child Justice Act. Also see Skelton and Badenhorst The Criminal Capacity of Children in South Africa 19.

${ }^{21} \mathrm{~S} 35(1)(\mathrm{g})$ read with S 11(3) of the Child Justice Act. Also see Skelton and Badenhorst The Criminal Capacity of Children in South Africa 19. 
suitably qualified person ${ }^{22}$ upon the request of the prosecution or the child's legal representative. ${ }^{23}$ The court may also order such an evaluation of its own accord. ${ }^{24}$ This evaluation must include an assessment of the cognitive, moral, emotional, psychological and social development of the child. ${ }^{25}$ Even though such an evaluation is not mandatory, some magistrates feel compelled to order such an evaluation since they are not trained to determine the criminal capacity of a child. ${ }^{26}$ The Judicial Matters Amendment Act, ${ }^{27}$ however, imposed an obligation on the inquiry magistrate or childjustice court to consider the cognitive, moral, emotional, psychological and social development of a child when making a decision regarding the criminal capacity of a child. ${ }^{28}$ This obligation will arguably result in a further increase of referrals for enquiry by a suitably qualified person into the criminal capacity of the child. The increase in referrals is the logical result of an inquiry magistrate or child-justice court wanting to satisfy itself that it considered all developmental aspects properly, before making an order pertaining to the child's criminal (in)capacity. Where an evaluation of the child's criminal capacity is ordered ${ }^{29}$ the person conducting the evaluation, must give consideration to all developmental aspects. The inquiry magistrate can rely on the report by the person who conducted the evaluation to comply with his obligation to consider the developmental issues of the child. The report of the medical expert, we, however, submit, is not determinative and must be viewed within the State's burden to prove criminal capacity beyond a reasonable doubt.

22 This is either a medical practitioner registered as such in terms of the Health Professions Act of 56 of 1974 against whose name the speciality of psychiatry is registered, or a clinical psychologist registered in terms of the Health Professions Act 56 1974. These persons have been identified as "suitably qualified" as per the Regulations pertaining to Determination of persons or category or class of persons competent to conduct the evaluation of criminal capacity of a child and the allowances and remuneration payable in respect of such persons published in R 273 GG 33092 2010-04-01.

$23 \mathrm{~S} 11(3)$ of the Child Justice Act. Also see Hawkridge in Kaliski (ed) Psycholegal Assessment in South Africa 254, who states that the requests mostly originate from the prosecutor who is required to rebut the doli incapax presumption.

24 S 11(3) of the Child Justice Act.

25 Ibid. Also see Skelton and Badenhorst The Criminal Capacity of Children in South Africa 44-45, for an explanation of what the measurement of cognitive, moral and social development entails. See further Gallinetti in Boezaart (ed) Child Law in South Africa 652. Regulation 13 of The Regulations relating to Child Justice R251 published on 31 March 2013 stipulate that an order for assessment by a suitably qualified person must be done on a form 2 which is included in these regulations. The Form stipulates that the report rendered to the court in accordance with s 11(4) must contain a description of how each of the developmental aspects of the child namely: cognitive, moral, emotional, psychological and social, was measured.

26 Skelton and Badenhorst The Criminal Capacity of Children in South Africa 26. Since the preliminary inquiry must be held within 48 hours of arrest and an assessment by the probation officer must be performed before the preliminary inquiry commences, the inquiry magistrate has very little information at hand to determine with certainty the criminal capacity of a child. This contributes to the increase in referrals of children for capacity enquiry, even though it is an expensive and time-consuming exercise.

$27 \quad 42$ of 2013.

28 S 2 of the Judicial Matters Amendment Act 42 of 2013 inserted a paragraph into s 11 of the Child Justice Act which placed this obligation on the inquiry magistrate or the child justice court.

29 In terms of $\mathrm{s} 11(3)$ of the Child Justice Act. 
The "routine referral" of children for evaluation of criminal capacity, places a burden on already scarce state resources within the pragmatic framework of the Act..$^{30}$ A shortage of personnel on the part of the Department of Health necessitates the use of private psychologists and psychiatrists for these evaluations, ${ }^{31}$ which is not only financially strenuous but also timeconsuming, especially in cases where a child is eventually diverted for a minor offence.

Procedurally the psychologist or psychiatrist conducting the evaluation of criminal capacity in terms of the Child Justice Act must furnish the court with a report within 30 days of date of the order for evaluation. ${ }^{33}$ The Act is, however, silent on whether the evaluation should be conducted at a certain venue. ${ }^{34}$ The Act further fails to regulate the initial time restraint on evaluation or whether the 30-day period may be extended. It appears that the evaluation need only be performed by one psychologist or psychiatrist regardless of the seriousness or violent nature of the alleged offence.

The inquiry magistrate must, when taking the decision as to the criminal capacity of the child, consider the assessment report of the probation officer $^{36}$ and all evidence placed before the court, including a report drafted by a suitably qualified person who evaluated the criminal capacity of the child (if it was requested) ${ }^{37}$ before referring for plea and trial, convicting the child or diverting the case. ${ }^{38}$ The Child Justice Act does not contain provisions pertaining to the procedure to be followed to dispute the report drafted by the psychologist or psychiatrist with regard to the criminal capacity of the child where two psychologists or psychiatrists may have

30 Skelton and Badenhorst The Criminal Capacity of Children in South Africa 50. See also Hawkridge in Kaliski (ed) Psycholegal Assessment in South Africa 254, who confirms that child and adolescent mental-health specialists in South Africa, are scarce and cannot perform all the pre-trail mental-health assessments as requested by the courts. Note, that this shortage or scarce skill was observed prior to the enactment of the Child Justice Act.

31 Skelton and Badenhorst The Criminal Capacity of Children in South Africa 22. Also see Hawkridge in Kaliski (ed) Psycholegal Assessment in South Africa 253, where it is pointed out that the professional that is used to conduct the inquiry, should not have had a prior privileged relationship with the child or his/her parents. This may cause delays in appointing a suitable person to conduct the inquiry but is an essential principle in order to ensure that the enquiry is objective.

32 Skelton and Badenhorst The Criminal Capacity of Children in South Africa 22 and 26. Even where private psychologists and psychiatrists are used, very few specialize in the area of forensic assessment of criminal capacity of children, resulting in even further delays.

$33 \mathrm{~S} 11(4)$ of the Child Justice Act. The period of 30 days is in line with the assessment period for criminal capacity as provided for in s 79(2)(a) of the Criminal Procedure Act.

34 Hawkridge in Kaliski (ed) Psycholegal Assessment in South Africa 254, indicates that an evaluation of criminal capacity of a child can be completed within two to four hours over several visits, or if several visits are not possible, in one visit with frequent breaks in between.

35 S 6 of the Judicial Matters Amendment Act 42 of 2013 read with s 46 of the Judicial Matters Amendment Act 42 of 2013 provides for different classes or categories of persons to be appointed to assess different aspects of development of a child that have to be considered during the inquiry into the criminal capacity of a child and as set out in s 11(3) of the Child Justice Act.

36 This report must be drafted in terms of $s 40$ of the Child Justice Act.

37 S 11(3) of the Child Justice Act. Also see Skelton and Badenhorst The Criminal Capacity of Children in South Africa 21.

38 Depending on the forum of the hearing as the case may be. S 11(2) of the Child Justice Act. 
opposing views concerning criminal capacity. This lack may be due to the fact that the Act provides only for one psychologist or psychiatrist to evaluate a child as pointed out above. ${ }^{39}$ This lacuna has, however, been addressed in an Amendment Act, ${ }^{40}$ which now makes the procedure as set out in section $77^{41}$ of the Criminal Procedure Act (which provides for an evaluation to be done by more than one psychiatrist depending on the seriousness of the charges) applicable to reports in respect of the criminal capacity of a child rendered in terms of the Child Justice Act. ${ }^{42}$

An issue which has not been addressed by the Judicial Matters Amendment Act, however, is that referral to a suitably qualified person for an evaluation of the criminal capacity of a child is not mandatory in terms of the Child Justice Act. ${ }^{43}$ The consequence is that the court has discretion in this regard. Although the court may refer there is a real possibility, especially in smaller areas of jurisdiction, or where court rolls are particularly full that the inquiry magistrate or child-justice court, might rely on the opinion of the probation officer who is not qualified to make an evaluation regarding criminal capacity but who is obliged to include an opinion on the possible criminal capacity of the child in the assessment report.

By contrast, the system in England and Wales is not troubled by the doli incapax doctrine which was abandoned. All children of 10 years and above are presumed to possess criminal capacity. The Crown, however, recognizes that a child who is mentally disordered is "doubly vulnerable". ${ }^{45}$ In determining whether the youth offender who labours under a mental disorder should be prosecuted the prosecutor is required to consider the seriousness of the offence, any history of offending, the nature of the child's mental disorder or disability, the likelihood of repetition and the availability of suitable alternatives to prosecution. ${ }^{46}$

39 See the wording of $s$ 11(3) that refers to "suitably qualified person".

40 S 8 of the Judicial Matters Third Amendment Bill 53 of 2013 read with s 46 of the Judicial Matters Amendment Bill 7 of 2013.

41 More in particular s 77(2), (3) and (4) of the Criminal Procedure Act which sets out the procedure to be followed where a report rendered by a mental health-care practitioner in respect of the mental condition of the accused, is disputed by any party. Provision is made for the hearing of evidence in such an instance where the person who conducted the assessment can be called to testify. Note, however, that $\mathrm{s} 77$ of the Criminal Procedure Act, sets out the procedure to be followed to ascertain if an accused person is fit to stand trial and not to ascertain if an accused person is criminally responsible. The section in the Criminal Procedure Act that sets out the procedure in respect of establishing criminal capacity of an accused, is $\mathrm{s} 78$ and it would possibly be more correct to rather include a reference to s 78(3), (4) and (5) into the Child Justice Act to stay within the same theme, rather than referring to s 77(2), (3) and (4) of the Criminal Procedure Act which deals with fitness to stand trial. The reference to $s 77$ rather than $s 78$ will not have serious practical implications as the relevant subsections of $\mathrm{s} 77$ and 78 referred to above, read the same.

42 As provided for in terms of s 11(3) read with s 11(4) of the Child Justice Act.

43 See the word "may" in s 11(3) of the Child Justice Act. Also see Gallinetti in Boezaart (ed) Child Law in South Africa 652-653, who also comments on the discretion that the court has in referring the child to a suitably qualified person for observation and that such a referral is not mandatory as is the case with the assessment to be done by the probation officer.

$44 \mathrm{~S} 40(1)(\mathrm{f})$ of the Child Justice Act.

45 Crown Prosecution Service "Youth with Mental Disorders, Including Learning Disabilities" $\mathrm{http}: / / \mathrm{www} . c p s . g o v . u k / l e g a l / v$ to z z/youth_offenders (accessed 2014-04-11).

46 Ibid. 


\section{Criminal Procedure Act}

Referrals in terms of section 78 of the Criminal Procedure Act occur where there is a suspicion that an accused lacks criminal responsibility due to mental illness or defect. ${ }^{47}$

The fact that the Child Justice Act contains its own provisions regarding the evaluation of the criminal capacity of a child, begs the question of the relevance of section 77 and 78, of Criminal Procedure Act. Although section 77 is expressly mentioned in the Child Justice Act, ${ }^{48}$ the procedure to be followed is not likewise stipulated. ${ }^{49}$ Skelton and Badenhorst are of the view that this lacuna may cause the child-justice court to believe that any doubt regarding the child's criminal capacity [or indeed mental health] has been attended to by the probation officer. ${ }^{50}$

Professionals who conduct evaluations of child offenders in terms of section 78 of the Criminal Procedure Act, are unsure as to how to report to the court after having conducted such an evaluation ${ }^{51}$ since the aim of a section 78 evaluation is to determine if the accused suffers from a mental illness or mental defect that affects his/her ability to distinguish between right and wrong, and act accordingly. The uncertainty stems from the fact that a child may lack criminal capacity, not because he/she suffers from a mental illness or defect but because he/she is not mature enough to meet the criteria for criminal capacity, which fact is not connected to the child's mental health per se.

Psychiatrists and clinical psychologists have reported that the measuring instruments used to determine a child's criminal capacity are inadequate, ${ }^{52}$ which uncertainty may be a contributing factor to the low number of specialists in this field. Those who do conduct evaluations, use their own methods since there is no standardized approach ${ }^{53}$ or uniform model for the

S 78 of the Criminal Procedure Act.

48 S 48(5)(b) of the Child Justice Act dealing with the postponement of a preliminary inquiry in the event that a child has to be referred for an enquiry in terms of s 77 or 78 of the Criminal Procedure Act.

49 Skelton and Badenhorst The Criminal Capacity of Children in South Africa 23.

50 Ibid. The Child Justice Act does not specifically require the probation officer to consider a referral in terms of $s 77$ or 78 of the Criminal Procedure Act in drafting his report to the Court. We support the notion that the "gap" created by the dual system of referral for criminal capacity (on the one hand in terms of the Child Justice Act with regard to children between 10 and 14 years and on the other hand in terms of the Criminal Procedure Act) must be bridged.

51 Skelton and Badenhorst The Criminal Capacity of Children in South Africa 24 and 28.

52 Pillay "Criminal Capacity in Children Accused of Murder: Challenges in the Forensic Mental Health Assessment" 20091 Journal of Child and Adolescent Mental Health 17 21. Also see Skelton and Badenhorst The Criminal Capacity of Children in South Africa 44, where it is confirmed that the assessment of criminal capacity of children is an underdeveloped field that requires research and clinical development nationally and internationally. They also indicate that the tests currently used to measure criminal capacity include an assessment of intelligence. The intelligence-quotient tests are, however, based on the Western notion of intellectual ability and are not necessarily applicable to South African children. The validity and reliability of such measuring instruments may therefore prove to be agents of discrimination as opposed to tools of fair assessment.

53 Skelton and Badenhorst The Criminal Capacity of Children in South Africa 51. 
evaluation of a child's criminal capacity. ${ }^{54}$ This compromises the reliability of the evaluations in that other professionally-used sui generis methods may possibly reach a different conclusion.

\section{LACK OF CRIMINAL CAPACITY - CONSEQUENCES AND CONCERNS}

\section{Child Justice Act}

Where the prosecutor is of the view that criminal capacity of a child between 10 and 14 years is not likely to be proved, the charges must be withdrawn and the child referred to a probation officer who processes the child in accordance with section 9 of the Child Justice Act which contains provisions pertaining to the manner of dealing with children under the age of 10 years. ${ }^{55}$ The rebuttable presumption of lack of criminal capacity is presumably no longer applicable to a child between 10 and 14 years at this stage in the proceedings, as the child is now dealt with as if under the age of 10 years and therefore deemed to lack criminal capacity in totality with no option of proving that the child does indeed possess criminal capacity. ${ }^{56} \mathrm{~A}$ finding of incapacity is, we submit, not a "once-and-for-all decision", however, and each case against a child is judged on its merits in regard to capacity.

The probation officer, to whom the child is referred in section 9, may take a variety of actions, including, but not limited to, arranging counselling or therapy. ${ }^{57}$ The probation officer can set up a plan pertaining to the child stipulating certain goals to be achieved. This includes assistance to be received by the child, ${ }^{58}$ details of the service provider who will provide these services $^{59}$ and the time within which they should be provided. ${ }^{60}$ If the child fails to adhere to the plan, the matter will be referred to the Children's Court to be dealt with in terms of the Children's Act. ${ }^{61}$ The matter will thus become a civil matter and will stay out of the criminal justice system. The procedure is indicative of the welfarist nature of parts of the South African child justice process.

54 Skelton and Badenhorst The Criminal Capacity of Children in South Africa 28.

55 S 11(5) read with S 9 of the Child Justice Act. Also see Skelton and Badenhorst The Criminal Capacity of Children in South Africa 20.

56 The Regulations relating to Child Justice R251 published on 31 March 2013 and in particular regulation 54 , stipulate that a register of all children who are not criminally responsible. This includes children under the age of 10 years who came into conflict with the law who are presumed to lack criminal capacity altogether, as well as children between the ages of 10 and 14 years whose criminal capacity could not be proved beyond a reasonable doubt, and who were referred to the probation officer in terms of $s 11(5)$ of the Child Justice Act.

57 S 9(3)(ii) of the Child Justice Act. The measures taken by the probation officer can also take the form of arranging support services for the child (s ((3)(iv)) or arranging a meeting to ascertain the circumstances of the allegations against the child (s 9(3)(v) read with s 9(4)).

58 S 9(5)(b) of the Child Justice Act.

59 S 9(5)(c) of the Child Justice Act.

$60 S$ 9(5)(a) read with s (9)(5)(b) and (c) of the Child Justice Act.

$61 \mathrm{~S} 9(7)$ of the Child Justice Act. The child shall be dealt with in terms of Chapter 9 of the Children's Act 28 of 2005. 
Should the child be found doli capax, the child may be diverted away from the criminal justice system, ${ }^{62}$ or the matter will proceed to trial in a child justice court.

The English system of youth justice recognizes, as part of the system of police cautions and conditional cautions that the mental state of the youth interferes with the application of alternatives to prosecution for children suffering mental defect or disability. Much like diversion in South Africa, the English caution and conditional-caution systems, require the child to acknowledge responsibility for the act or omission. This is of particular concern in cases of mentally disordered youth, more so where mens rea is an element of the alleged crime. The same concern is, however, applicable to cases where a child between 10 and 14 is diverted pre-trial in terms of Chapter 6 of the Child Justice Act with no reference to an objective assessment of criminal capacity.

\section{Criminal Procedure Act}

If a person is found to lack the capacity to understand the proceedings or to suffer from a mental defect or illness rendering the accused not responsible for a criminal act or omission, the court may make various orders premised on the severity of the original charge. ${ }^{64}$

If the accused was charged with murder, culpable homicide, rape, compelled rape or any other act involving serious violence, but lacks the necessary mental status to be held criminally responsible, the accused must be found not guilty. ${ }^{6}$

The court may then direct that:

(i) the accused be detained in a psychiatric institution as a state patient in terms of the Mental Health Care Act. ${ }^{66}$ A state patient will be released only upon order by a judge in chambers; ${ }^{67}$

(ii) the accused be detained in a psychiatric institution as an involuntary mental health-care user; ${ }^{68}$

(iii) the accused be discharged conditionally; ${ }^{69}$ and

(iv) the accused be discharged unconditionally. ${ }^{70}$

In accordance with Chapter 8 of the Child Justice Act read with Chapter 7 of the Regulations relating to Child Justice R251 published on 31 March 2013.

63 Skelton and Badenhorst The Criminal Capacity of Children in South Africa 19 and 25, where it is reiterated that diversion is not possible where the child lacks criminal capacity.

64 S 78(6)(b)(i) read with 78(6)(b)(ii) of the Criminal Procedure Act.

$65 \mathrm{~S} 78(6)(\mathrm{a})$ of the Criminal Procedure Act.

66 S 78(6)(b)((i)(aa) of the Criminal Procedure Act read with S 47 of the Mental Health Care Act 17 of 2002.

67 S 78(6)(b)(i) of the Criminal Procedure Act.

$68 \mathrm{~S} 78(6)(\mathrm{b})(\mathrm{i})(\mathrm{bb})$ of the Criminal Procedure Act read with s 37 of the Mental Health Care Act 17 of 2002.

69 S 78(6)(b)(i)(dd) of the Criminal Procedure Act.

70 S 78(6)(b)(i)(ee) of the Criminal Procedure Act. 
If the accused is found to have committed an act other than murder, culpable homicide, rape, compelled rape or an act that did not involve violence, the court may make one of three orders as listed in (ii)-(iv) above. $^{71}$

The consequences of a finding of non-criminal responsibility are significantly less serious in terms of the Child Justice Act, than the Criminal Procedure Act, since a finding in terms of the Criminal Procedure Act, which can result in detention in a psychiatric institution, either as a state patient or an involuntary mental health-care user. $^{72}$ It is doubtful whether the therapy that may be prescribed by a probation officer in terms of section 9 of the Child Justice $\mathrm{Act}^{73}$ includes detention in a psychiatric institution, even as a voluntary mental health care user.

Where a child is found to lack criminally responsibility in accordance with section 78 of the Criminal Procedure Act, the consequences of such a finding are uncertain when measured against the best-interest standard. The "sanctions" that are usually associated with a finding of non-criminal responsibility following an inquiry in terms of section 78 of the Criminal Procedure Act, will/should not apply to a child dealt with in terms of the Child Justice Act. Bearing this in mind, the purpose of an assessment of a child in terms of section 78 of the Criminal Procedure Act becomes unclear.

\section{THE CRIMINAL PROCESS FOR CHILDREN BETWEEN THE AGES OF 10 AND 14 IN THE SOUTH AFRICAN CRIMINAL PROCEDURE}

The initial concern facing the criminal justice system when a child between 10 and 14 comes into contact with the law is the issue of capacity. Capacity or rather the lack of it in this case is a presumption of law that can be refuted by the prosecution. The lack of capacity is, in other words, not a defence to the charge or allegation but rather a consideration of law which must be resolved before any question of indictment can occur.

\section{Procedural issues arising from the doli incapax presumption}

\section{The determination of capacity by a prosecutor in the case of a schedule 1 offence}

Where a child between 10 and 14 is alleged to have committed a schedule 1 offence the prosecutor may decide to do away with the assessment ${ }^{74}$ and

\footnotetext{
71 S 78(6)(b)(ii)(aa), (cc) and (dd) of the Criminal Procedure Act. Where a person is found not to have committed a serious offence or where it is found that the person did in fact commit the offence but that it was not a serious offence, such a person cannot be declared a state patient and can at most be treated as an involuntary mental health-care user in terms of $s$ 37 of the Mental Health Care Act 17 of 2002.

S 78(6) of the Criminal Procedure Act.

In terms of $\mathrm{s} 9$ of the Child Justice Act.

${ }^{4} S$ 41(3) of the Child Justice Act.
} 
refer the child for diversion without any reference to a court of preliminary inquiry. In these instances the prosecutor is required to consider the potential criminal capacity of the child before making such a decision. The factors upon which these considerations are premised are those indicated at paragraph 2(b) above. Whilst the authors are not opposed to the use of prosecutorial discretion in the diversion of a child accused of a relatively minor offence they are concerned that the capacity of the child is then a matter of arbitrary determination, based on vague and subjective factors, as opposed to proved beyond a reasonable doubt before an impartial arbiter. The prosecutor is in effect given powers of adjudication and therein must determine whether the onus of proof is satisfied. Yet, there is no opportunity granted for the doli incapax presumption to be rebutted.

Further the Child Justice Act makes no reference to the position of a child afflicted with a mental defect or illness (not related to a lack of capacity on the presumption of immaturity) and there is no fail-safe mechanism for referral for observation in terms of section 78 of the Criminal Procedure Act. In effect the prosecutor could determine the child to possess criminal capacity to act and refer to diversion without any consideration of mens rea. Granted the prosecutor's decision must be confirmed by a magistrate in chambers, but the Act makes no provision for the determination of mental disorder or defect which is doubly alarming when the probation officer's opinion on the matter is omitted by reason of the prosecutor's decision to forego assessment.

The prosecutor may likewise decide to refer a schedule 1 matter to the court of preliminary inquiry, where diversion is unsuitable, based on the factors mentioned in section 52(1)(a)-(e) and in this process, any mental defect or illness could be raised. We, however, submit that prosecutors are not trained to assess the mental status of a child and therefore it is also conceivable that, having established criminal capacity, a child suffering from a mental defect or illness could be diverted in terms of Chapter 6 of the Child Justice Act without his/her mental illness being duly considered, possibly resulting in non-treatment of the condition and potential recidivism as the underlying cause of the criminal behaviour (if it is indeed linked to mental illness) if it is not addressed.

\section{The determination of capacity by a court of preliminary inquiry}

As has been discussed supra the court of preliminary inquiry must consider a variety of evidential aspects including the assessment report by the probation officer and a variety of vague subjective characteristics specific to the child, in order to determine whether such a child has the requisite degree of criminal capacity to be charged and prosecuted for an act or omission. The court of preliminary inquiry is, however, supported in this endeavour by its ability to order an evaluation of the child by a suitably qualified person. In our submission it is at this stage that section 77 and 78 of the Criminal Procedure Act collide with the presumption of incapacity. The only instance in which the Child Justice Act makes mention of Chapter 13 of the Criminal Procedure Act is at section 48(5)(b) which permits the court of preliminary 
inquiry to postpone the inquiry pending the completion of a section 77 , or 78 evaluation of the child. The aspects of capacity are dealt with separately, indicating the legislator's separation of criminal capacity from mental defect or illness. Incapacity, as a presumption, is not in and of itself a defence or ground of justification, whereas mental defect or illness may establish a justification even if only to the degree of diminished capacity.

\section{Trial in the child-justice court}

During trial in the child-justice court the state must prove beyond reasonable doubt that a child between 10 and 14 has the requisite degree of criminal capacity. The standard test for capacity is:

(i) Could the child appreciate the difference between right and wrong; and

(ii) could the child act in accordance with that appreciation?

The above test of capacity is stated in section 11(1) of the Child Justice Act as the grounds upon which the presumed incapacity of the child can be refuted. It is, stated otherwise, the test of capacity by reason of age status and not mental defect or illness. The same test is stated in section 78 of the Criminal Procedure Act but, we submit, that the test of capacity in the Criminal Procedure Act relates to the defence of mental incapacity and not incapacity by status of age. The two tests should therefore not be considered as one and the same, nor should the procedure they embody. With regard to the proof of criminal capacity for children between the ages of 10 and 14 Skelton states "Although the onus rests on the state to prove criminal capacity, there is no legal obligation to prove it prior to putting charges to the child or at any specific stage during the prosecution. This means that the child might have to go through the entire process of a trial before a decision is made. ${ }^{, 75}$ This assertion cannot be supported in light of both the aims and objectives of the Child Justice Act and the best-interest standard. The proof of capacity is at issue in the assessment by the probation officer, chapter 6 diversion where applicable, and at the preliminary inquiry ably supported by medical expertise on the question of capacity. It is unfathomable how a child would be referred to plea and trial where there was any doubt regarding criminal capacity at the pre-trial stage. To suggest otherwise would be to suggest that criminal capacity can wax and wane and should ultimately be decided only by the child-justice court. The only way in which such a situation could occur is where the child refuses to acknowledge responsibility at the preliminary stage and is referred immediately to plea and trial. This, however, presents somewhat of an element of duress in that the capacity of the child, or lack thereof, can be sacrificed to his right to remain silent. Regardless of the child's acknowledgment or lack thereof the preliminary inquiry ought to be able to decide before asking for such acknowledgment whether the child has criminal capacity. To set this process in the inverse is to place the child in a pre-trial situation in a manner contrary to the presumption of the lack of criminal capacity.

75 Skelton "Proposals for the Review of the Minimum Age of Criminal Responsibility" 2013 South African Journal of Criminal Justice 257264. 


\section{The "triple illusion" of proof beyond a reasonable doubt}

The Child Justice Act allows the prosecution three chances to prove criminal capacity - once in terms of chapter 6 (with the attached reservation we discussed above), at the preliminary inquiry and at trial in the child-justice court. Why the "three strikes" approach was taken to the proof of capacity is debatable and in our submission simply provides the prosecution with the opportunity to prove its case again regardless of initial uncertainty. This cannot be in the best interest of the child or the administration of justice. We submit that capacity is a matter which must be determined at the pre-trial stage and should not be a matter for the child-justice court. Where incapacity, or mental defect, as a defence in terms of the Criminal Procedure Act, is raised, however, the court of child justice is the better arbiter of this defence.

\section{The pathology of the average and the punishment of maturity}

The doli incapax doctrine functions as a device which effectively raises the minimum age of criminal capacity. In the ordinary course of events the average child between 10 and 14 lacks the necessary maturity to act with any degree of capacity - at least this is the theory underlying the presumption. A rebuttal of the presumption should in essence be an exception rather than the rule. There is, however, evidence that the exception is interpreted as the normal practice and in this manner "average" or "normal" children are being categorized as capable when they are not. The aim of evaluation according to Skelton is to prove that "only the few who are suspected of possessing abnormal maturity ... [are] subjected to scrutiny of their criminal capacity and if their abnormal maturity is confirmed, to be considered for diversion or prosecution". ${ }^{77}$ We, however, submit that the application of doli incapax presents an alternative challenge to legal certainty within the rule of law as a value of the Constitution. Working from Skelton's assertion that only those of "abnormal maturity" should undergo prosecution or diversion, one can easily argue that the law sets a penance for maturity which places the fair and equal application of law on a slippery slope of potential discrimination. By way of analogy - the law stipulates that a child under the age of 16 cannot purchase tobacco products - this applies to all persons under the age of 16 . The law does not permit a particularly mature 14-year-old any leeway to argue that he should be permitted to purchase cigarettes based on his "abnormal maturity". Admittedly, underage smoking is a different sphere to criminal conduct - it, however, demonstrates a valuable point - the criminal law is over-inclusive which is perhaps why most "normal" children are being labelled as mature enough to stand trial as opposed to the intention of the legislature in this regard.

\footnotetext{
Skelton 2013 South African Journal of Criminal Justice 266. Ibid.
} 


\section{Procedural concerns arising from the application of section 77 and 78 of the Criminal Procedure Act}

The capacity question in section 77 and the mental-status question in section 78 are distinct from the determination of criminal capacity in a child between 10 and 14. The provisions of the Criminal Procedure Act are defences against criminal conduct whereas the doli incapx is a presumption. That being said, it is conceivable that a child (regardless of whether between the ages of 10 and 14 or 14 and over, and thus capable) is mentally incapable, defective or ill and requires assessment in terms of the Criminal Procedure Act. The text of the Child Justice Act is clear in section 48(5)(b) that a preliminary inquiry can be postponed for an evaluation in terms of Chapter 13 of the Criminal Procedure Act, thus demonstrating that the evaluation of capacity based on age status is distinct from evaluation based on mental incapacity or illness. Our concern, over and above the different standards of proof required by the Criminal Procedure Act and the shifting of the onus to the child-accused where he avers mental defect or illness, is the manner in which section 79 regulates the assessment of an accused (adult or child) who relies on the provisions of section 77 or a section 78 defence. We address our concerns regarding the lack of child-friendly procedure evident in section 79 through the interpretation of specific sub-sections thereof.

\section{The offence - driven nature of the procedure - section 79(1)(a) and (b)}

Section 79 designates different professionals to different levels of offence:

(i) Where the accused is indicted for murder, culpable homicide, rape, compelled rape or any other charge involving serious violence the court shall direct the enquiry to be conducted by the medical superintendent of a psychiatric hospital designated by the court (or a psychiatrist appointed by the superintendent); by a psychiatrist appointed by the court who is not in the full-time service of the state; by a psychiatrist appointed for the accused by the state; and by a clinical psychologist where the court so directs.

(ii) Where the alleged offence does not fall into the categories mentioned in (i) above, the court can direct that the enquiry be conducted and reported on by the superintendent of a court-designated psychiatric hospital or by a psychiatrist appointed by the medical superintendent at the request of the court.

Clearly the number and independence of specialists appointed in terms of the Criminal Procedure Act increase based on the severity of the crime and yet the Child Justice Act purports to be offender as opposed to offence driven. The distinction is slight but questions can be raised in a child justice system which handles the child informally and individualistically in the pretrial phase, but then switches its concentration to the offence and the need for public protection as soon as mental defect or illness is raised in the context of the Criminal Procedure Act. 


\section{Time constraints}

For any inquiry in terms of section 77 or 78 the court may order that the child offender be remanded to a psychiatric hospital for a period not exceeding 30 days, which may be extended for a further period in the absence of the accused where no objection is raised to the extension in absentia. In terms of the Child Justice Act, however, remand to a psychiatric hospital, is a form of pre-trial or trial detention which incurs strict limitations in the best interest of the child. The Child Justice Act only permits the detention of a child in either a child-and-youth-care centre or a prison where the child has appeared at a preliminary inquiry, or where his trial has been postponed. The Child Justice Act does not authorize the detention of a child in a psychiatric hospital and in these instances authority for the court's order is found within section 79 of the Criminal Procedure Act. This is, however, problematic from a best-interest perspective. Where a child is detained in a prison the child must be brought before the court every 14 days to reconsider the order of prison detention. If one reads "detention in a psychiatric hospital" into the ordinary meaning of "prison" neither the Child Justice Act nor the Criminal Procedure Act requires that a child under psychiatric observation be produced before the court at regular intervals, and the latter further permits the extension of the 30-day evaluation period in the absence of the child-offender. This must be viewed in light of the fact that legal representation is not mandatory at the preliminary inquiry stage (where logically the first opportunity for referral for evaluation arises).

\section{Orders under section 79}

Once a section 77 or 78 enquiry has been completed the court may order that the child-accused be referred to a court in section 77 (6) for trial, ${ }^{78}$ make any order it deems fit regarding the custody of the accused or make any other order. The Child Justice Act, however, limits the orders for custody open to the court in terms of section 79 due to the restrictions in placement contained in sections 29 and 30 of the Child Justice Act.

\section{THE CRIMINAL PROCESS FOR CHILDREN SUFFERING A MENTAL DEFECT OR LEARNING DISABILITY IN THE ENGLISH/WELSH PROCESS}

England/Wales do not have a doli incapax provision which makes direct contrast on the determination of criminal capacity as a status concern impossible. Their criminal process does, however, provide for the trial of young persons with learning disabilities in a youth court or Crown Court, depending on the situation. The English system does not criminally try those who do not have the mental faculties to make a proper defence or who were incapable, at the time of the offence, of distinguishing the difference between right and wrong and act in accordance with that appreciation. Their system

78 In the case of an accused found unfit to stand trial in terms of $s 77$ of the Criminal Procedure Act, trial refers to a trial on the facts before the court and not a trial in the true sense of the word. 
does, however, allow for the trial of a child who has learning disabilities as determined by $R$ on the application of TP $v$ West London Youth Court. ${ }^{79}$ According to the Crown Prosecution Guidelines on Youth Justice, ${ }^{80}$ trying a child who suffers from a learning disability does not breach Article 6 of the European Convention on Human Rights, provided that the child can understand what he is alleged to have done, the court is satisfied the youth had the means of knowing that the act or omission was wrong, the youth understands the defences available and has had the necessary time to make representations informed by the nature of the matter at hand. The court is the upper guardian of the child in these cases and must ensure that the child fully understands the proceedings and that his mental or intellectual disability is not used as a weapon in cross-examination. The English system attempts to try the youth and makes all allowances for the mental or intellectual impairment before it stays the proceedings in cases where it is apparent that the child cannot effectively participate. In the matter of CPS v $P^{81}$ the court gave guidance on the procedure where the defence raised the child's incapacity as a defence (as would be the case in South Africa where a child raises the provisions of section 77 or 78 of the Criminal Procedure Act at trial). The Administrative court held:

(i) One finding of incapacity is not a blanket defence to all subsequent acts or omissions - each matter is decided afresh.

(ii) Where the court undertakes an examination of whether the child did indeed commit the act or omission alleged (akin to a section 77(6) procedure in South Africa), such proceeding is not considered a criminal trial. Hence the defendant child's Article 6 rights are not engaged and his participation in the fact-finding process is not essential. The fact-finding process is appropriate where the court is contemplating a guardianship or hospital order under section 37(3) of the Mental Health Act 1983. Where the court on fact-finding cannot establish guilt the child must be acquitted but an order to local authorities for care proceedings may be in order.

(iii) Medical opinion is not the determinative factor but the matter is for the court to decide. The court, in deciding, must consider the medical evidence, any evidence of the alleged offence, evidence of the youth behaviour at arrest and interview, what the youth stated in the arrest interview, and the interaction between the judge and child in the court setting.

In essence the defence of incapacity (based on learning disability or mental disorder) is a defence in English law which does not preclude trial but which establishes grounds for an alternative process at trial. Questions of status (age) incapacity are irrelevant since England abandoned the doli incapax presumption.

79 R on the application of TP v West London Youth Court [2005] EWHC 2583 Admin, 2583 (Administrative Court 2005).

80 Crown Prosecution Service "Youth with Mental Disorders, Including Learning Disabilities" http://www.cps.gov.uk/legal/v_to_z/youth_offenders (accessed 2014-04-11).

81 CPS v P [2007] EWHC 946 Admin, 946 (Administrative Court 2007) 946. 


\section{CONCLUSION AND RECOMMENDATIONS}

The minimum age of criminal capacity of a child, which is currently 10 years, ${ }^{82}$ must be reviewed within 5 years of commencement of the Child Justice Act. ${ }^{83}$ Should the international trend be followed to adjust the age of criminal capacity of children from 10 to 12 years, many of the above issues with regard to age capacity will automatically resolve if the doli incapax presumption is abandoned with the change in minimum age of criminal capacity. ${ }^{84}$ A child will by virtue of age thus either be deemed criminally capable, or to lack criminal capacity - a strict model of age capacity will thus come into play.

In the interim the authors suggest:

1. Where a child is between the ages of 10 and 14 years his/her incapacity of age must be determined using the provisions of the Child Justice Act and not those of section 77 and 78 of the Criminal Procedure Act. The question raised by the doli incapax provision is not whether the child is mentally defective or ill but rather whether his level of maturity is sufficient to stand trial. Using the provisions of section 77 of the Criminal Procedure Act labels the child as suffering a pathological condition as opposed to simply being immature.

2. The presumption operative in the Criminal Procedure Act is that an accused is of normal mental function unless the contrary is proved by the party who raises the issue of mental defect or incapacity. The presumption in the Child Justice Act is that children between the age of 10 and 14 years lack criminal capacity unless the contrary is proved by the state beyond reasonable doubt. Reporting on the findings of an assessment of a child in terms of the Criminal Procedure Act, bearing the purpose thereof in mind, as set out above, is problematic and contrary to the best-interest standard. The Child Justice Act aims to create a separate criminal justice system for children, and having children between the age of 10 and 14 years assessed in terms of the Criminal Procedure Act, rather than the Child Justice Act, will defeat this purpose. $^{85}$

3. Where the court is faced with a situation where a child between the ages of 10 and 14 is also afflicted by mental defect or illness the vulnerability of the child is doubled. In these cases we suggest a two-pronged approach:

82 S 7(1) of the Child Justice Act.

$83 \mathrm{~S} 8$ of the Child Justice Act. See also in general Skelton and Badenhorst The Criminal Capacity of Children in South Africa which consists of research information aiming to assist government in taking a decision regarding the review of the age for criminal capacity.

84 Skelton and Badenhorst The Criminal Capacity of Children in South Africa 28, share this view. They add that the number of referrals for the evaluation of criminal capacity of children will be reduced, thereby making the already scarce mental-health resources available to children who are legitimately in need thereof. Also see Gallinetti in Boezaart (ed) Child Law in South Africa 652.

85 Hawkridge in Kaliski (ed) Psycholegal Assessment in South Africa 259, points out that even though assessments of criminal capacity of children should take place according to clinical protocol, particular ethical considerations should apply due to the fact that children are particularly susceptible to intimidation. The Criminal Justice system as it has been designed for adults could be extremely intimidating to a child. 
(i) The child's capacity based on age should be determined first, using the relevant provisions of the Child Justice Act. Where the child is found to be criminally incapable based on age he will be placed under the provisions of section 9 of the Child Justice Act. The child escapes liability based on his age incapacity and not on the grounds established in section 77 and 78 of the Criminal Procedure Act (and their resultant consequences). In this case the court should be empowered to order that the child receive a mental-health evaluation as part of section 9 proceedings and where necessary, be placed under involuntary observation in terms of mental-health laws. In this instance the Child Justice Act requires amendment to allow for the court to make such a determination. In the determination of capacity inquiry magistrates and child-justice court officials require training on the cognitive, moral, emotional, psychological and social development of children in order to enable them to give meaningful consideration to these aspects, especially in view of the fact that they will soon be obliged ${ }^{86}$ to do so when making an order pertaining to a child's criminal capacity. An alternative solution is to require probation officers to employ the services of a psychologist or psychiatrist before submitting the assessment report at court in order to facilitate the court's consideration of age capacity. Naturally, however, the restriction set by section 50 of the Criminal Procedure Act regarding the time restrictions on first appearance will undermine the probation officer's capacity to appoint such expert. We, however, submit that very few children between 10 and 14 are detained after arrest and most are released on written warning or summons to appear. The latter two procedures provide ample time for the probation officer to intervene and order the services of a suitably qualified medical expert to determine capacity.

(ii) Secondly, where the initial determination of age-based capacity determines that the child possesses the requisite degree of capacity to understand the difference between right and wrong and act in accordance therewith, but where mental illness or defect can be raised as defence ${ }^{87}$ the procedure determined in section 79 of the Criminal Procedure Act comes into operation. We, however, submit that section 79 of the Criminal Procedure Act is not child-friendly nor does it fulfil the best-interest standard of the child. This provision requires amendment or inclusion into the Child Justice Act with specific consideration given to the best-interest-of-the-child standard.

(iii) The procedure for children over the age of 14 who aver mental incapacity or defect will likewise require attention under the bestinterest banner since the onus and burden standards of the Child Justice Act differ greatly from those prescribed by the Criminal Procedure Act.

36 According to $s$ of the Judicial Matters Third Amendment Bill 53 of 2013.

87 As would be the case for example where a child can understand the difference between right and wrong and act in accordance with that appreciation but where his pathological condition (such as for the example the case with psychopathy) creates a ground of defence to the alleged act or omission. 
Ultimately, if the doli incapax doctrine is abandoned and the minimum age of criminal capacity is set at a certain age a procedural lacuna will still exist in the treatment of children who raise mental defect or illness as a defence. We submit that the Child Justice Act requires amendment to include specific provisions for these instances in which case the provisions of the Criminal procedure Act will have no effect on the child. 